\title{
耐震試験用ハイブリッド実験システムの制御系設計*
}

\author{
関健 太*1, 服部誠*2, 川福 基 裕*1 \\ 岩崎誠*2, 平井洋 武*1, 岸田一義*3
}

\section{Controller Design of Hybrid Experimental System for Seismic Tests}

\author{
Kenta SEKI*4, Makoto HATTORI, Motohiro KAWAFUKU, \\ Makoto IWASAKI, Hiromu HIRAI and Kazuyoshi KISHIDA \\ ${ }^{* 4}$ Department of Computer Science and Engineering, Nagoya Institute of Technology, \\ Gokiso, Showa-ku, Nagoya-shi, Aichi, 466-8555 Japan
}

\begin{abstract}
Hybrid experimental system is one of powerful tools to perform various seismic tests for unknown and/or huge structures, where an actuator-excited experimental vibratory system and a computational response analysis are on-line combined and are simultaneously conducted. This paper presents a control methodology for high performance hybrid experimental systems. A 2-degrees-offreedom compensator is applied from the viewpoint of control techniques, where a FB compensator is designed according to the system stabilization analysis and a FF compensator is designed to achieve the desired servo characteristics. In the FF compensator design, an iterative learning control system is especially adopted to eliminate the time delay in actuator responses. The proposed compensation algorithm has been verified using an actual hybrid experimental set up with 2-mass structure.
\end{abstract}

Key Words: Hybrid Experimental System, Seismic Tests, Control Design, Iterative Learning Control, Hydraulic Actuator

1. 緒

地震に対する構造物全体の振動応答評価法の一つと して, 振動台を用いた加振実験が挙げられる ${ }^{(1)}$. しか し，実際の構造物を振動台上に建設して振動試験を行 うことは, 経済的.時間的に大きな負担となる. さら に, 高層ビルや高架橋といった大規模な構造物の振動 試験には, 実験設備に限界がある. 一方で, 計算機に よる数値解析が幅広く実施されているが, その解析精 度は数値解析モデルの精度に大きく依存する.

これらの問題点を解決する手法として，ハイブリッ ド実験といわれる手法が考案され, 活発に研究が行わ れている(2). この手法は, 数学的に解析が困難, ある いはモデル化が非常に複雑な要素の諸特性のみを加振 実験により抽出し，これをオンラインで計算機内に取 り込み，全体系の数值解析を進めるものである. その

* 原稿受付 2006 年 12 月 20 日

*1 正員, 名古屋工業大学大学院情報工学專攻(画466-8555 名 古屋市昭和区御器所町).

*2 名古屋工業大学大学院情報工学専攻.

*3 (株) 日立プラントテクノロジー研究開発本部土浦研究所 (者300-0013 土浦市神立町 603).

E-mail : k-seki@nitech.ac.jp
ため, 比較的小さな加振設備で構造物全体の振動応答 を精度良く評価できる利点がある. ハイブリッド実験 は, 部材の変形過程の観察や復元力特性の検証を目的 に, 加振実験の時間軸を拡大した仮動的実験として広 く使われ発展してきたが ${ }^{(3)(4)}$, その手法では摩擦ダン パーや粘性ダンパー等のように応答が速度に大きく依 存する供試体に対して正確な評価を行うことができな い. そこで, 加振実験の時間軸を一致させ, ハイブリッ ド実験を実時間で行うリアルタイムハイブリッド実験 が提案されている ${ }^{(5)}{ }^{(7)}$. リアルタイムハイブリッド 実験においては，指令值に対する加振機の応答遅れが 実験精度の劣化のみならず，実験システムの不安定化 の原因となることが知られており，その補償法が極め て重要となる. 従来, 加振機の応答遅れ補偵法として, 堀内らは, 加振信号に多項式関数を外挿することで加 振機の応答遅れを予測・補僙する手法 ${ }^{(6)}$ を提案し, 所 定の周波数範囲内では良い補償特性を持つことを実験 により検証している，一方，五十嵐らは，加掁機の振 幅, 位相特性をキャンセルするデジタルフィルタ, 即 ち逆伝達関数を加掁信号に付加し, 所定の周波数範囲 内で良い補頱特性を持つことを実験により検証してい 
$\Xi^{(7)}$. しかし，いずれの方式も，加振可能な周波数が 約 10[Hz] 以下に制限されることや，加振機のモデル 化誤差, 動特性の微小変化により実験精度及び実験シ ステムの安定性が大きく劣化する問題を有している.

本研究では, 上記課題に対して, 制御技術的アプ ローチにより実験システムの安定性を大幅に改善した 上で, 加振機の応答遅れを補償し，10[Hz] 以上の周波 数領域においても加振実験を可能とすることで, 高精 度な振動応答評価の獲得を可能とする制御手法を提案 する. 具体的には, 実加振部と数值計算部を含めた八 イブリッド実験を一つの制御システムとして捉え, 制 御システムを安定化するフィードバック (以降, FB) 補僙器と加振機の目標値追従特性を向上させるフィー ドフォワード (以降, FF) 補償器を, 独立に設計する 2 自由度制御系の考え方を導入する.ここで, 特に FF 補償器設計においては, 反復学習制御アルゴリズムを 適用する. 提案手法の検証では，小型の油圧加振機を 用いた実加振部と 2 慣性系を数值モデルとして用いた 数値計算部の構成によるハイブリッド実験システムに より，その有効性を示す.

\section{2. ハイブリッド实験システムと従来制御手法}

$2 \cdot 1$ ハイブリッド实験システムの概要 図 1 に, ハイブリッド実験システムの概略図を示す，評価対象 構造物の一部分を実物 (以降，実物モデル) として持 ち, 他の部分は計算機上に数値モデルとして持つ. 数 値モデルの運動方程式は, 次式で与えられる.

$$
M \ddot{x}+C \dot{x}+K x=f+f_{r}
$$

ここで, $M, C, K$ はそれぞれ数値モデルの質量, 减 衰, 剛性マトリクス, $x$ は相対変位ベクトル, $f$ は地 震などによる外カベクトル， $f_{r}$ は数値モデルと実物モ デルの境界点に作用するカベクトルであり， $f_{r}$ は境界 点の変位 $x_{b}$ を用いて形式的に,

$$
f_{r}=f_{r}\left(x_{b}, \dot{x_{b}}, \ddot{x_{b}}, \cdots\right)
$$

と表現できる. 加振実嗱により実物モデルから計測し た力 $f_{r}$ をオンラインで計算機に取り込み, 式 (1)に代 入することで評価対象構造物の振動応答を計算でき, その時に求められる境界変位 $x_{b}$ を加振機により実物 モデルに与え， $f_{r}$ を計測する．以上を繰り返すこと で, 構造物全体の数值計算によって振動応答を評価す る. そのため, 数值モデルにより計算される境界変位 $x_{b}$ (加振機への変位指令となる) と実物モデルの応答変 位を一致させることは, 精度の高い振動応答評価を行 うために必須である。

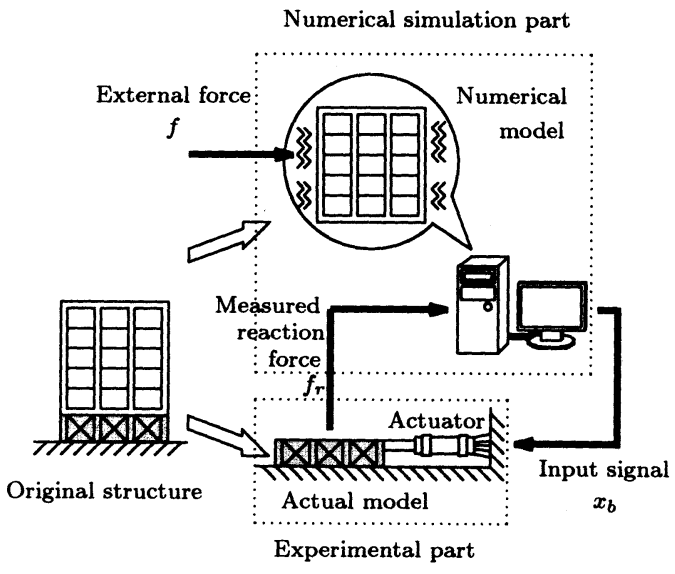

Fig. 1 Hybrid experimental system.

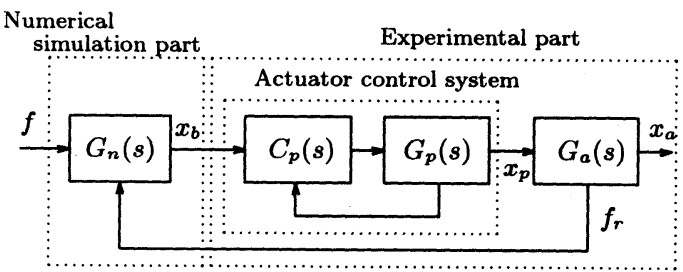

Fig. 2 Block diagram of hybrid experimental system.

ここで, 図1に示すハイブリッド実験システムをブ ロック線図で表記すると図 2 となる. 図中, $f$ は地震 などによる外力, $x_{b}$ は数値モデルと実物モデルの境 界変位, $x_{p}$ は加振機変位, $x_{a}$ は実物モデルの応答変 位, $f_{r}$ は加振実験により計測される力, $G_{n}(s)$ は数值 モデルの伝達関数, $C_{p}(s)$ は加振機 $\mathrm{FB}$ 補偵器, $G_{p}(s)$ はサーボアンプ, サーボ弁, ピストン, 静圧継手から なる油圧加振機の伝達関数, $G_{a}(s)$ は実物モデルの伝 達関数である. 加振機制御系は変位 FB 制御系を構成 し, 加振機の安定性と十分な外乱抑圧特性を確保する ものである. 図 2 より, ハイブリッド実觶システムは 数値モデルと実物モデル，加振機制御系を含む一つの FB 制御系を構成しているので，制御技術的アプロー チでシステムを高性能化することが可能である.

2.2 システム構成と評価対象權造物 本研究の ハイブリッド実験システムの制御系設計に際しては, 加振機の加振方向は水平方向のみとし, 評価対象構造 物を図 3 に示す 2 慣性系とした.ここでは， $K_{1}, C_{1}$ を実物モデルとして加振実験を行い，残りの部分は数 值モデルとして数值計算を行う. 各機械パラメータを 


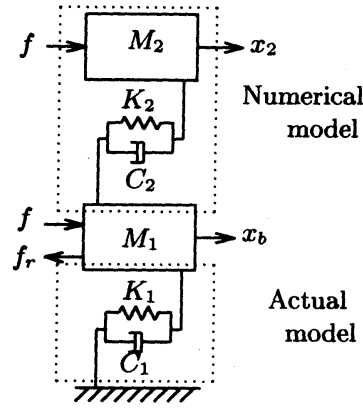

Fig. 3 Original structure of 2-mass system.

Table 1 Parameters of 2-mass system.

\begin{tabular}{|c|c||c|c|}
\hline$M_{1}[\mathrm{~kg}]$ & 21.5 & $M_{2}[\mathrm{~kg}]$ & 21.9 \\
\hline$C_{1}[\mathrm{~N} /(\mathrm{m} / \mathrm{s})]$ & 23.6 & $C_{2}[\mathrm{~N} /(\mathrm{m} / \mathrm{s})]$ & 94.3 \\
\hline$K_{1}[\mathrm{~N} / \mathrm{m}]$ & $3.3 \times 10^{4}$ & $K_{2}[\mathrm{~N} / \mathrm{m}]$ & $5.7 \times 10^{4}$ \\
\hline
\end{tabular}

表 1 に示す．加振機制御系は，前述の通り変位 FB 制 御系を構成しており, その一巡伝達特性のナイキスト 線図を図 4 に, FB 特性 (図 2 中 $x_{b}$ から $x_{p}$ ) を図 5 に 示す. 図 4 より, 加振機制御系は十分な安定性を有し ていることがわかる．また，図 5 より，加振機制御系 の追従特性は約 $10 \mathrm{~Hz}$ までゲインが $0[\mathrm{~dB}]$ となってい るが，位相遅れの影踥で目標値と実応答には位相差が 存在する.

2.3 従来の制御手法 ハイブリッド実験におい ては, 図 5 に示す加振機の応答遅れが実験精度の劣化 のみならず, システムの安定性低下の原因となる.こ こでは, 加振機の応答遅れ補偵の代表的な従来手法で ある予测手法 ${ }^{(6)}$ を取り上げ, 制御系設計の観点からこ の手法の特性とその欠点を検討する.

予測手法は，加振機の応答遅れ時間 $\delta t$ 分だけ先の 振動応答を予測して加振機への変位指令とする手法で ある. 予測式を次式に示す。

$$
\widehat{x_{b}}=\sum_{i=0}^{n} a_{i} x_{b}(i)=a_{0} x_{b}(0)+a_{1} x_{b}(1)+\cdots
$$

ここで, $\widehat{x_{b}}$ は予測值, $n$ は予測の次数, $x_{b}(0)$ は現時 刻の計算值, $x_{b}(i)$ は現時刻よりも $(\delta t \times i)$ 前の計算値, $a_{i}$ は次数により決まる定数である. 即ち, 予測式は加 振機の応答遅れ時間 $\delta t$ をサンプリング時間とした, 次 式のパルス伝達特性を有するフィルタと考えられる.

$$
\widehat{X_{b}(z)}=\left(a_{0}+a_{1} z^{-1}+a_{2} z^{-2}+\cdots\right) X_{b}(z)
$$

式 (4) は予測式が位相進み補償器であることを示して おり, 例えばその次数を 3 次, 各定数 $a_{0} \sim a_{3}$ を文献 (6) に記载されている值とし, 加振機応答遅れ時間 $\delta t$

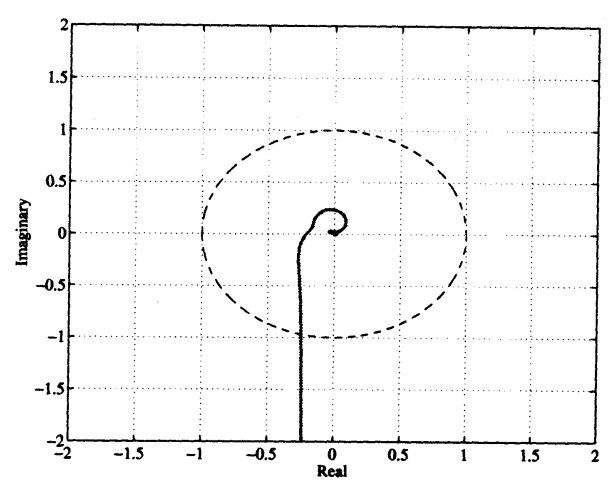

Fig. 4 Nyquist diagram of actuator control system.
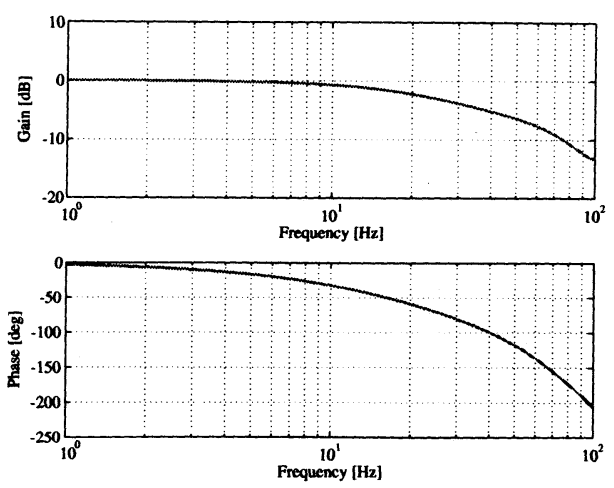

Fig. 5 Frequency characterintic of actuator control system.

を $10[\mathrm{~ms}]$ とすると，その周波数特性は図 6 となる. 式 (4) は図 2 のブロック線図おいて, ハイブリッド実験 システムの FB 補償器として作用する. 即ち, 位相進 みにより FB制御系の安定性を確保していると考えら れる. 一方で, 式 (4) は加振機制御系から見た場合, 前向き補償器として作用する. 図 7 に, 図 5 の周波 数特性を有する加振機制御系と実物モデル, 図 6 の予 測フィルタを乗算した周波数特性を示す. 図より，約 $10 \mathrm{~Hz}$ 以下の周波数領域においては, 加振機の応答遅 れをキャンセルして, ゲイン, 位相ともにフラットな 特性を得ていることから，境界変位 $x_{b}$ と実物モデル 応答変位 $x_{a}$ を一致させることができる．しかし，高 周波数領域でゲインが増大しているため, 観测ノイズ や油柱共振 (液体内に粗密波が発生し，ピストンが振 動する現象) ${ }^{(8)}$ ，ディザー信号 ${ }^{(9)}$ の影響を受け易い. さらに, 図 8 は数值モデルを含めたハイブリッド実験 システム全体の一巡伝達特性のナイキスト線図である が，この図から安定余有が非常に少なくなっているこ とがわかる. そのため, 加振機の微小な特性変動の影 

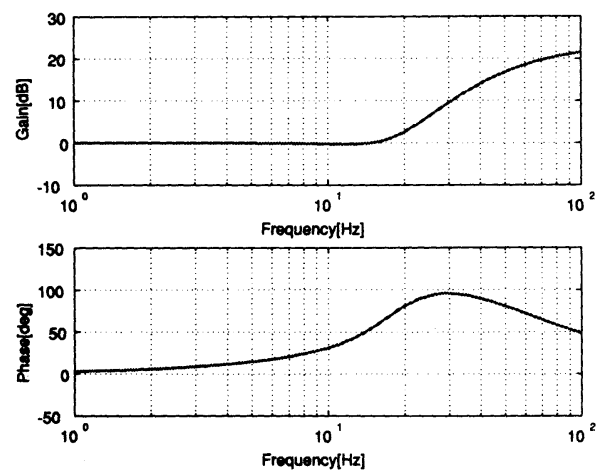

Fig. 6 Charactristic of predictive filter.
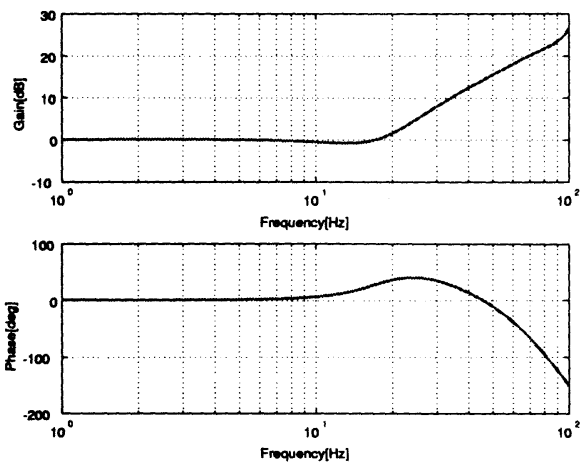

Fig. 7 Frequency characteristic of experimental part with predictive filter.

梆によりシステムが不安定になると考えられる.

\section{3. ハイブリッド实検システムに対する制御系設計}

$3 \cdot 1$ 制御系設婛指針 前述のように, 予測手法 は 1 自由度制御系設計の考え方でシステムの高性能化 を図っていると捉えることができる. そのため，ハイ ブリッド実験システムの安定性と加振機の目標値追従 特性向上を同時に考虑して，加振可能な周波数帯域を 桩大することには限界があると考えられる．そこで， 本研究では FB 制御系の安定性と，目標值追従特性の 向上を独立に設計可能な 2 自由度制御系の考え方を導 入し，加振可能な周波数帯域の拡大を図る. 即ち,

・ ハイブリッド実験システムの安定性を確保する FB 補供器の設計,

- 境界変位 (加振機変位指令) $x_{b}$ と実物モデル応 答変位 $x_{a}$ を一致させる, 反復学習による FF 補 偵器の設計,

のそれぞれにより，ハイブリッド実験システムにおい て加振可能な周波数帯域の拡大を図る.

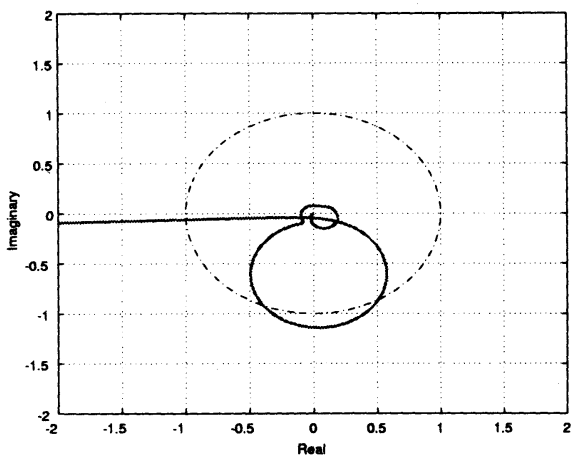

Fig. 8 Nyquist diagram of hybrid experimental system with predictive filter.

Table 2 Parameters of stabilization compensator.

\begin{tabular}{|c|c||c|c|}
\hline$\zeta_{n}$ & 0.71 & $\omega_{n}[\mathrm{rad} / \mathrm{s}]$ & $2 \pi \times 2.0$ \\
\hline$\zeta_{d}$ & 0.71 & $\omega_{d}[\mathrm{rad} / \mathrm{s}]$ & $2 \pi \times 5.0$ \\
\hline
\end{tabular}
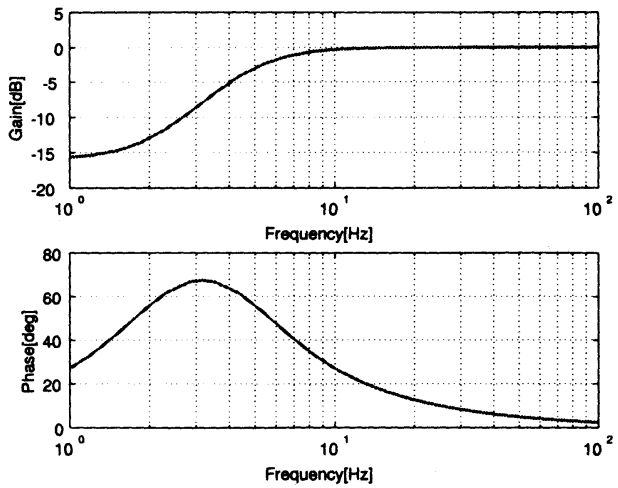

Fig. 9 Frequency charactristic of $C_{s}(s)$.

3.2 FB 補賃器の設計 ハイブリッド実験シス テムの安定性向上のためには，位相特性の改善が不可 欠である，そこで，本研究では次式に示す 2 次の位相 進み補償器 $C_{s}(s)$ を設計する.

$$
C_{s}(s)=\frac{s^{2}+2 \zeta_{n} \omega_{n} s+\omega_{n}^{2}}{s^{2}+2 \zeta_{d} \omega_{d} s+\omega_{d}^{2}}
$$

各パラメータは, ハイブリッド実験システムにおける 一巡伝達特性のゲイン交差周波数付近の位相を $60^{\circ}$ 程 度進めるよう調整した．設計した補償器の各パラメー 夕を表 2 に，その周波数特性を図 9 に示す．また，図 9 の位相進み補償器を付加した制御系を図 10 に，その 一巡伝達特性のナイキスト線図を図 11 に示す。図 11 より，設計した位相進み補償器を付加することで位相 余裕は $55^{\circ}$ 程度確保され, 図 8 に示寸従来手法に比 べ安定性が大幅に改善されていることがわかる. 


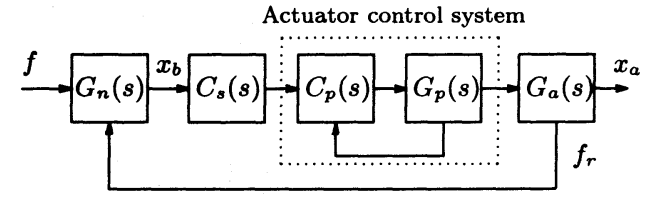

Fig. 10 Block diagram of hybrid experimental system with $C_{s}(s)$.

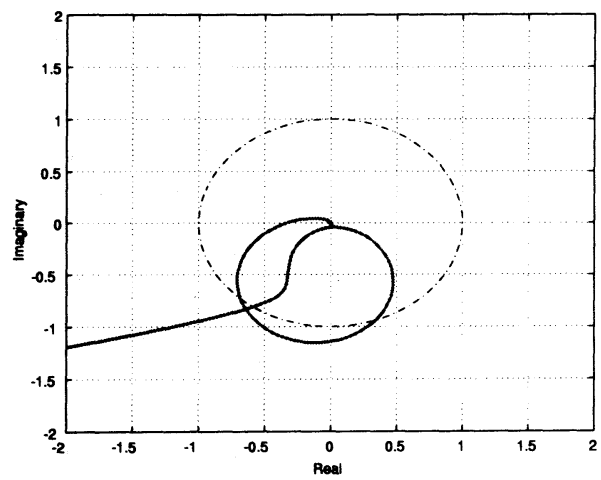

Fig. 11 Nyquist diagram of hybrid experimental system with $C_{s}(s)$.

しかし, 位相進み補僙器 $C_{s}(s)$ は加振機制御系から 見た場合，前向き補偵器として作用する．即ち，図 9 に示す $C_{s}(s)$ の特性から, 低周波数領域でのゲイン低 下は避けられず，その影響で加振機の追従特性が劣化 してしまう.そこで, ハイブリッド実験システムの安 定性とは独立に追従特性の改善を図る FF 補償が必須 となる.

\subsection{FF 㭪賃器の設咭}

3.3.1 反侮学漗による FF 信号の生成 ハイブ リッド実験においては, 試験内容が評価対象構造物の 非破壊試験である場合には，絽り返し試験が可能であ る. 本研究では, その特徴を利用して, 反復学習制御 により境界変位指令 $x_{b}$ と実物モデル変位 $x_{a}$ を一致さ せるための FF 信号の生成を行う。なお, 実際の加振 実験においては，実物モデルの変位を計測することは 困難であるため，加速度を計測することになる．その ため, 境界加速度 $\ddot{x_{b}}$ と実物モデル加速度 $\ddot{x_{a}}$ が一致す るような反復学習制御器とする. 実際, 加速度信号が 一致していれば, 速度, 変位とも十分一致していると 考えられる.

図 12 に, 反復学習制御器を含めたハイブリッド実験 システムのブロック線図を示す.ここで, $G_{1}(s)$ は境 界加速度 $\ddot{x}_{b}$ から境界変位 $x_{b}$ までの伝達特性, $G_{2}(s)$
は反力 $f_{r}$ から境界加速度 $\ddot{x_{b}}$ までの伝達特性, $G_{3}(s)$ は前述の位相進み補償器, 加振機制御系, 実物モデル を含めた, 境界変位 $x_{b}$ から実物モデルの加速度 $\ddot{x_{a}}$ ま での伝達特性, $G_{4}(s)$ は実物モデルの加速度 $\ddot{x_{a}}$ から 反力 $f_{r}$ までの伝達特性, $u$ は反復学習により生成さ れる補正信号である: なお， $k$ は反復学習における $k$ 回目の試行を表す.この反復学習制御器は, 境界加速 度 $\ddot{x_{b}}$ と実物モデル加速度 $\ddot{x_{a}}$ を入力とし, 両者の誤差 $e$ が零へ収束するように後述の学習則 $W(s)$ を乗じて 補正信号 $u$ を生成する.ただし， 1 回目の試行におい ては, $u_{1}=0$ である.

3.3.2 学習則の橧出 学習則 $W(s)$ を以下のよ うに導出する. 図 12 より, $k$ 回目の試行における各 伝達特性は,

$$
\begin{aligned}
\ddot{x}_{a k} & =G_{1}(s) G_{3}(s) \ddot{x_{b k}}-G_{3}(s) u_{k} \\
\ddot{x}_{b k} & =f+G_{2}(s) G_{4}(s) \ddot{x_{a k}} \\
e_{k} & =\ddot{x_{a k}}-\ddot{x_{b k}}
\end{aligned}
$$

となり, 式 (6), (7), (8) をまとめると, $k$ 回目の誤差 $e_{k}$ は次式で表される。

$$
e_{k}=\frac{\left\{G_{1}(s) G_{3}(s)-1\right\}}{\alpha} f-\frac{\beta}{\alpha} u_{k}
$$

ここで, $\alpha=1-G_{1}(s) G_{2}(s) G_{3}(s) G_{4}(s)$,

$$
\beta=G_{3}(s)\left\{1-G_{2}(s) G_{4}(s)\right\} \text { である. }
$$

従って, $k+1$ 回目の試行における補正信号 $u_{k+1}$ は,

$$
\begin{aligned}
u_{k+1}= & W(s) e_{k}+u_{k} \\
= & \frac{\left\{G_{1}(s) G_{3}(s)-1\right\} W(s)}{\alpha} f \\
& +\left(1-\frac{\beta}{\alpha} W(s)\right) u_{k}
\end{aligned}
$$

となり，この漸化式を解くと次式となる.

$$
u_{k}=(-\gamma)\left(1-\frac{\beta}{\alpha} W(s)\right)^{k-1}+\gamma
$$

ここで, $\gamma=\frac{G_{1}(s) G_{3}(s)-1}{\beta} f$ である.

式 (11) を式 (9) に代入すると,

$$
e_{k}=\left(1-\frac{\beta}{\alpha} W(s)\right)^{k-1} \frac{G_{1}(s) G_{3}(s)-1}{\alpha} f
$$

となる.ここで, 試行 1 回目の誤差 $e_{1}$ は式 (9) より,

$$
e_{1}=\frac{\left\{G_{1}(s) G_{3}(s)-1\right\}}{\alpha} f \quad\left(\because u_{1}=0\right)
$$

となるので, 式 (12) より次式を得る.

$$
e_{1}=\left(1-\frac{\beta}{\alpha} W(s)\right)^{k-1} e_{1}
$$




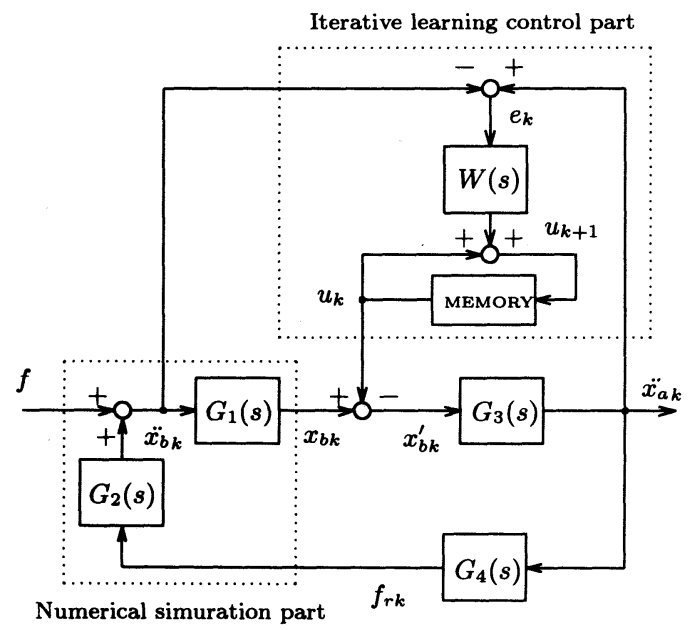

Fig. 12 Block diagram of hybrid experimental system with iterative learning controller.

即ち, 式(14)より,

$$
\left|1-\frac{\beta}{\alpha} W(s)\right|<1
$$

の条件を満たすとき, 誤差 $e_{k}$ は零に収束する. 式 (15) より,

$$
\begin{aligned}
W(s) & =\frac{\alpha}{\beta} \\
& =\frac{1-G_{1}(s) G_{2}(s) G_{3}(s) G_{4}(s)}{G_{3}(s)\left\{1-G_{2}(s) G_{4}(s)\right\}}
\end{aligned}
$$

とすれば, 最も少ない試行回数で誤差 $e_{k}$ は零に収束 し, 境界加速度 $\ddot{x_{b}}$ と実物モデル加速度 $\ddot{x_{a}}$ を一致させ ることができる.

3.3.3 FF 倍易生成手順 導出した学習則 $W(s)$ において, $G_{3}(s), G_{4}(s)$ は加振機及び実物モデルの特 性が含まれるため正確にモデル化することは困難であ る. そのため, 本研究では試行毎に得られる $x_{b k}^{\prime}, \ddot{x_{a k}}$, $f_{r k}$ の各信号をフーリエ変換し,

$$
\begin{aligned}
G_{3}(s) & =\frac{\ddot{X}_{a k}(s)}{X_{b k}^{\prime}(s)} \\
G_{4}(s) & =\frac{F_{r k}(s)}{\ddot{X}_{a k}(s)}
\end{aligned}
$$

により $G_{3}(s), G_{4}(s)$ を試行毎に同定する. また, 補正 信号 $u_{k}$ の生成は加振実験毎にオフラインで行い, 式 （16）を用いた補正信号 $u_{k}$ の演算は周波数領域で行う (10).これにより, 式 (16) が非プロパ及び非最小位相 系であっても実現できる. また, 加振周波数以上の不 必要な信号成分はマスク処理することで考慮しないこ ととする. 上記 FF 信号の生成手順を図 13 に示す.

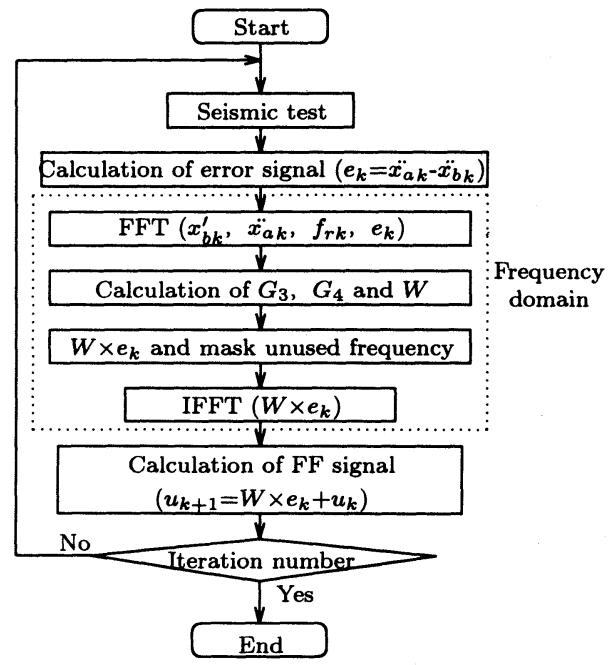

Fig. 13 Flowchart of proposed method for iterative learning control.

\section{4. 実 給 果}

提案手法の有効性を実験により検証する. 本研究で は, 高い周波数での加振機追従特性向上の効果をより 明確に示すため, 加振周波数帯域を $10[\mathrm{~Hz}] \sim 40[\mathrm{~Hz}]$ と し，図 14 に示す擬似加速度を入力信号として用いた. 学習試行回数は 3 回であり, 加振する実物モデルは表 1 の $K_{1}, C_{1}$ の值となるよう梁とダンパで構成し, 数值 演算, 及び各補償器はサンプリング時間 $0.2[\mathrm{~ms}]$ とし て, Digital Signal Processor(DSP)により実装した。 実験結果を図 15 , 図 16 に示す. 各図は試行 1 回目と 3 回目の実験結果であり, 数值モデルと実物モデルの 境界加速度 $\ddot{x_{b}}$ と実物モデルの応答加速度 $\ddot{x_{a}}$ の時間応 答波形及び $\ddot{x_{b}}$ と $\ddot{x_{a}}$ の誤差信号を示している. それぞ れの実験において, システムが安定に動作しているこ とが確認できる.また, 図 15 より試行 1 回目におい ては, 位相遅れの影響により $\ddot{x_{b}}$ と $\ddot{x_{a}}$ の間で誤差が生 じているものの, 試行を重ねることで誤差が减少し, 試行 3 回でほぼ一致することが確認できる. 即ち, 加 振実験により数值計算ステップ毎に必要な反力が正確 に求めることができ, より高い周波数まで精度の高い 振動応答評価が可能であることが確認できる.

\section{5. 結君}

本論文では, ハイブリッド実験システムを一つの制 御システムとして捉え, 制御系設計の観点からシステ ムを高性能化する 2 自由度制御手法を提案し, 実験に よりその有効性を検証した。そこでは，FB 補償器に よりシステム全体の安定性を十分に確保しながら反復 

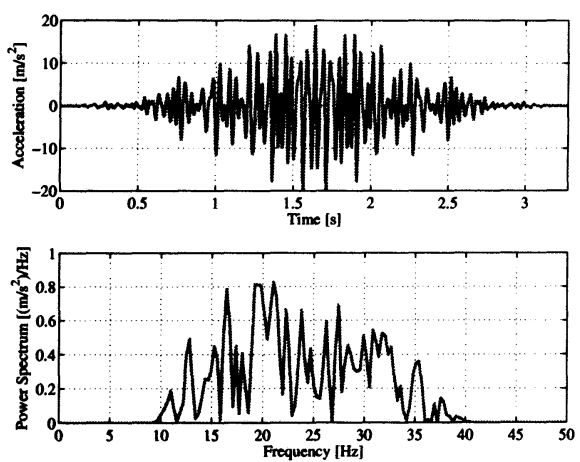

Fig. 14 Waveform and frequency power spectrum in desired acceleration signal.
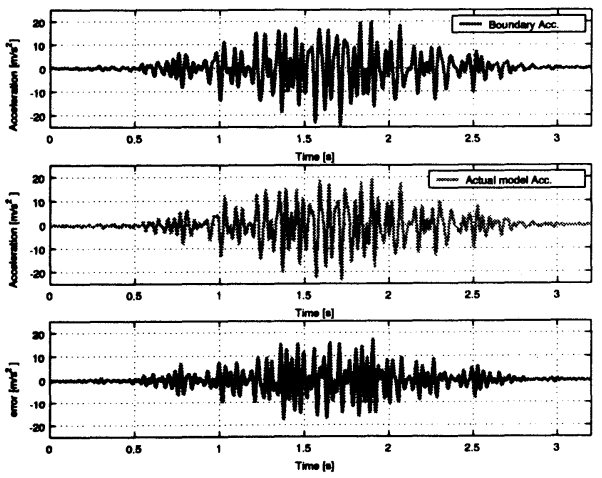

Fig. 15 Experimental results (1st trial).
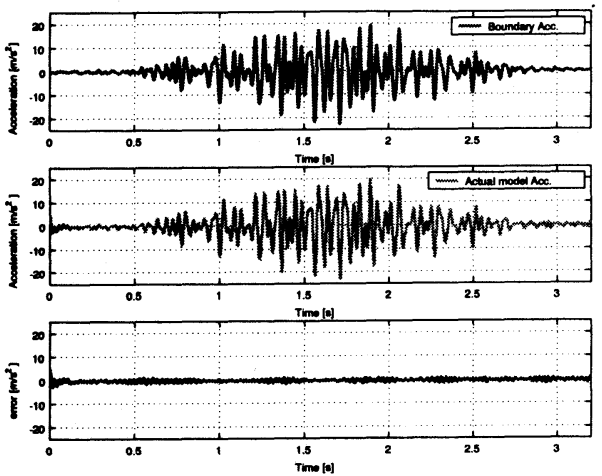

Fig. 16 Experimental results (3rd trial).

学習により追従性を向上する FF 信号を生成した．そ の結果, $40 \mathrm{~Hz}$ までの周波数を含む地震波に対しても 数值モデルと実物モデルの境界加速度と実物モデルの 応答加速度を加速度の次元で一致させることが可能と なり, 精度の高い振動応答評価が可能であることを示
した.

本研究では, 加振実験が繰り返し行え, かつ振動応 答の再現性があることを前提に反復学習制御を適用し たが，再現性のそしい構造物に対する補償方法につい ては稿を改め報告したい.

\section{6. 甜甜}

本研究において, 解析及び実験にご協力いただいた, 名古屋工業大学大学院博士前期課程伊藤健介氏, 樋川 祥弘氏, (株) 日立プラントテクノロジー 社会・産業シ ステム事業本部保田和輝氏に感謝致します。

\section{文献}

(1) Kajiwara, K., et al., Shaking performance of 3-D Full Scale Earthquake shaking Table (E-Defense) and applications after construction, Proceedings of the Motion and Vibration Control, Vol.9th (2005-8), pp.313-316.

(2) Iemura, H., Development and Future Prospect of Hybrid Experiments, Proceedings of the Japan Society of Civil Engineers, No.356 (1985), pp.1-10.

(3) Takanashi, K. and Nakashima, M., Japanese Activities on On-Line Testing, Journal of Engineering Mechanics, ASCE, Vol.113, No.7 (1987), pp.1014-1032.

(4) Dozono, Y., et al., Verification for a New Hybrid Seismic Experimental Method Combining Nonlinear Finite Element Analysis and Loading Test, Proceedings of the Motion and Vibration Control, Vol.9th (2005-8), pp.323-328.

(5) Nakagawa, M., et al., Development of a RealTime On-Line Vibration Testing System by Substructuring Method, Transactions of the Japan Society of Mechanical Engineers, Series C, Vol.60, No.570 (1994), pp.412-417.

(6) Horiuchi, T., et al., Development of a Real-Time Hybrid Experimental System with Actuator Delay Compensation (1st Report, Compensation Method and Application to Experiments of Single-Degreeof-Freedom Systems), Transactions of the Japan Society of Mechanical Engineers, Series C, Vol.61, No.584 (1995), pp.1328-1336.

(7) Igarashi, A., et al., The Real-Time Hybrid Test System Using Digital Filter Compensation, Japan Earthquake Engineering Symposium, Vol.11th (2002-11), pp.1633-1636.

(8) Neild S.A., et al., Control issues relating to real-time substructuring experiments using a shaking table, Earthquake Engineering and Structural Dynamics, Vol.34, No.9 (2005), pp.1171-1192.

(9) Ota, Y., Trouble of Servo Valve and its action (in Japanese), Proceedings of the hydraulic technique, Vol.20, No.11 (1981), pp.19-23.

(10) Igarashi, H., et al., Fast-Response and HighPrecision Positioning Using Iterative Learning Control, Papers of Technical Meeting on Industrial Instrumentation and Control,IIC,IEE Japan, Vol.IIC03, No.45-52.54-73, (2003), pp.19-24. 